\title{
CHARACTERIZATION OF PLACENTAL MESENCHYMAL STEM CELLS SPHEROIDS AFTER GENERATION, HYPOTHERMIC AND SUBNORMOTHERMIC STORAGE
}

\author{
V.Yu. Prokopiuk ${ }^{1 *}$, N.S. Hloba ${ }^{2}$, O.S. Prokopiuk ${ }^{3}$, A.O. Schedrov ${ }^{2}$, I.B. Musatova ${ }^{1}$ \\ ${ }^{1}$ Institute of Problems of Cryobiology and Cryomedicine, NAS of Ukraine, Kharkiv, Ukraine \\ ${ }^{2}$ Kharkiv National Medical University, Kharkiv, Ukraine \\ ${ }^{3}$ State Enterprise "Interdepartmental Scientific Center of Cryobiology and Cryomedicine", NAS, AMS of Ukraine \\ and the Ministry of Health of Ukraine, Kharkiv, Ukraine \\ *Corresponding author: v.yu.prokopiuk@gmail.com
}

Received 5 July 2019; Accepted 14 August 2019

\begin{abstract}
Background. Placental mesenchymal stem cells application is a promising area of cell therapy for number diseases. Their using in the form of spheroids results in enhancement of the therapeutic potential, improve the cells survival after transplantation. Medical purposes require the characterization and development of spheroids storage technology.

Objective. The aim of the paper is to characterize placental mesenchymal stem cells spheroids after generation and low-temperature storage.

Methods. Spheroids were produced by a hanging drop method from placental mesenchymal stem cells, characterized after production and after subnormothermic $\left(20^{\circ} \mathrm{C}\right)$ and hypothermic $\left(4^{\circ} \mathrm{C}\right)$ storage for up to $96 \mathrm{~h}$. The structure, metabolic activity of spheroids according to the data of the MTT test and the resazurin restoration test were studied.

Results. The hanging drop method makes it possible to produce from $1 \times 10^{6}$ placental mesenchymal stem cells about $825.3 \pm 56.2$ spheroids in the size of 50-150 microns and $62.3 \pm 5.1$ spheroids of $150-300$ microns in size, having a spherical shape, not stained with trypan blue, stained with neutral red and fluorescein diacetate. The spheroids adhere to the plastic and destroying through short-time centrifugation. During subnormothermic storage spheroids, structural characteristics and metabolic activity change after $48 \mathrm{~h}$, during hypothermic - after $24 \mathrm{~h}$ of storage.

Conclusions. The hanging drop method makes it possible to produce about 900 spheroids from 1 million placental MSCs with stable metabolic activity. For medical purposes, subornorthomeric $\left(20^{\circ} \mathrm{C}\right)$ storage not more than $24 \mathrm{~h}$ is recommended for placental MSC spheroid. Longer storage leads to a sharp decreasing of their metabolic activity and destroying to the separated cells.
\end{abstract}

Keywords: spheroids; mesenchymal stem cells; placenta; hypothermia; subnormothermia.

\section{Introduction}

Placental mesenchymal stem cells (MSCs) are promising candidates for cell therapy. Their advantages to cells from other sources are a high proliferative activity, reduced immunogenicity, and lack of ethical issues. Their effectiveness in the treatment of diabetes mellitus, ulcers, burns, neuropathy, premature ovarian failure, climacteric syndrome, infertility has been demonstrated. The stem cells mechanism of action is associated with their plasticity, paracrine, and endocrine properties [1,2].

The stem cells application in spheroids opens new possibilities in cell therapy. In spheroids, cells interact, actively secrete biologically active substances, live longer after transplantation. The effectiveness of stem cells spheroids in wounds healing, bone systems pathology, cardiovascular systems pathology, premature ovarian failure has been shown $[3,4]$.

For effective clinical application, it is important to characterize the properties of spheroids after generation and short-term storage, which is necessary for its transportation from the biotechnological laboratory to the clinic [5]. In our previous studies, we have proved inappropriate of cryopreservation for spheroids storage [6]. In our view, subnormothermic $\left(20^{\circ} \mathrm{C}\right)$ and hypothermic $\left(4^{\circ} \mathrm{C}\right)$ regimes are promising for the spheroids short-term storage. Their effectiveness is demonstrated on other objects $[7,8]$.

Aim of the study: to characterize spheroids from placental mesenchymal stem cells after production and low-temperature storage. 


\section{Materials and methods}

The research was conducted in the framework of the project "Investigation of geroprotective and gerotherapeutic effects of placental bioobjects" (No. 0114U00131).

The placenta was obtained whit women informed consent after cesarean section. Placental MSCs were isolated by the enzymatic method described earlier, cells were characteristics like MSCs (immunophenotype CD90 +, CD73+, CD105+, CD34-, capable of induced differentiation in the adipogenic, chondrogenic and osteogenic directions) [8].

Spheroids from the cell culture were generated by the hanging drop method [4, 9]. In brief: placental cells removed from plastic, resuspended in medium DMEM (BioWest, France) at a concentration of $5 \times 10^{5}$ cells $/ \mathrm{ml}, 30 \mu \mathrm{l}$ drops of were put to the inner surface of the cover of a nonadjuvant Petri dish. In the lower part of a Petri dish, $20 \mathrm{ml}$ of sterile distilled water were poured to save humidity. After $24 \mathrm{~h}$, spheroids, formed in drops were gently washed off and removed.

Spheroids were stored in DMEM (BioWest, France) in closed polypropylene tubes under subornorthomeric $\left(\sim+20^{\circ} \mathrm{C}\right)$ and hypothermic $\left(\sim+4{ }^{\circ} \mathrm{C}\right)$ conditions. Every $24 \mathrm{~h}$, a MTT (3-(4,5-dimethylthiazol-2-yl)-2,5-diphenyltetrazolium bromide) and resazurin tests, were done. Freshly isolated spheroids were used as a positive control, as negative spheroids, devitalized by $96 \%$ ice-cold ethanol.

An optical microscopy study with phasecontrast methods, neutral red, trypan blue vital staining, confocal laser scanning microscopy with fluorescein diacetate and propidium iodide (FDA/PI) staining according to previously described protocols $[6,8]$ were done.

For the MTT test, spheroids in concentration $1 \times 10^{5}$ cells $/ \mathrm{ml}$ were incubated for $4 \mathrm{~h}$ in 12 -well plates in the DMEM medium with the addition of MTT (Sigma, USA) at a final concentration of $0.5 \mathrm{mg} / \mathrm{ml}$ in a $\mathrm{CO}_{2}$ incubator (Thermo Fisher Scientific, USA) at $37^{\circ} \mathrm{C}$ in an atmosphere with $5 \% \mathrm{CO}_{2}$. After incubation, the medium was removed, the formazan was extracted with $96 \%$ ethanol and absorbance was measured on a spectrophotometer PV 1251C (Solar, Belarus) at a wavelength of $570 \mathrm{~nm}$. The resazurin test was performed similarly, resazurin (Sigma, USA) was added at a final concentration of $0.15 \mathrm{mg} / \mathrm{ml}$, incubated for $24 \mathrm{~h}$. The optical density was measured on a spectrophotometer PV 1251C (Solar, Belarus) at a wavelength of $590 \mathrm{~nm}$.

ToupView V 3.7 software (Hangzhou Toup Tek Photonics Co. Ltd, Hangzhou, China) was used for image processing. To obtain statistically significant conclusions, the Man-Whitney U-criterion and Kruskal-Wallis criterion were used. For data processing Past V. 3.15 software (University of Oslo, Norway) was used.

\section{Results}

From a suspension of $1 \times 10^{6}$ cells, $825.3 \pm$ \pm 56.2 spheroids in the size of $50-150$ microns and $62.3 \pm 5.1$ spheroids in the size of $150-300$ microns were obtained. Spheroids had a spherical shape, have not been stained with trypan blue. A small number of cells did not form spheroids (Fig. 1a). After FDA/PI staining, most cells were viable, except for a small number of cells on the periphery of spheroids (Fig. 1b).

All spheroids were adhesive to plastic and formed a monolayer during the day after moving to an adhesive culture dish (Fig. 1c). Viable spheroids were stained with formazan after MTT reaction. It was impossible to visualize individual cells to evaluate their viability as described in the literature for alginate microspheres [10] (Fig. 1d). Viable spheroids also were stained with neutral red without the possibility of visualizing individual cells (Fig. 1e). were stained with trypan blue. Cells in not viable spheroids loss their adhesive properties were separated from each other (Fig. 1f). Cell contacts between cells in spheroids were weak: the spheroids keep the integrity after the concentration by the washing and sedimentation, but after washing by centrifugation spheroids where destroyed.

After one day spheroids subnormothermic storage their number did not differ from the control index. The MTT and resazurin tests indexes were also at the control level (Table 1). Spheroids partially changed their shape, some cells were detached on their surfaces, it can be explained by intercellular adhesion decreasing, the cytoplasm became more granular (Fig. 2a).

After longer spheroids storage in the subnormothermic conditions, their number decreased, metabolic activity decreased twice (Table 2). At the morphological study, cells were separated from the spheroids, the cytoplasm was more vacuolated, amorphous (Fig. 2b).

When hypothermic spheroids storage their metabolic activity decreased significantly after $24 \mathrm{~h}$ of storage, changes progressed rapidly with each day (see Table 2).

At the morphological study, cells in spheroids significantly lost adhesion after $24 \mathrm{~h}$ (Fig. 2c), after $48 \mathrm{~h}$ the cytoplasm structure was altered by cell vacuolization (Fig. 2d). 

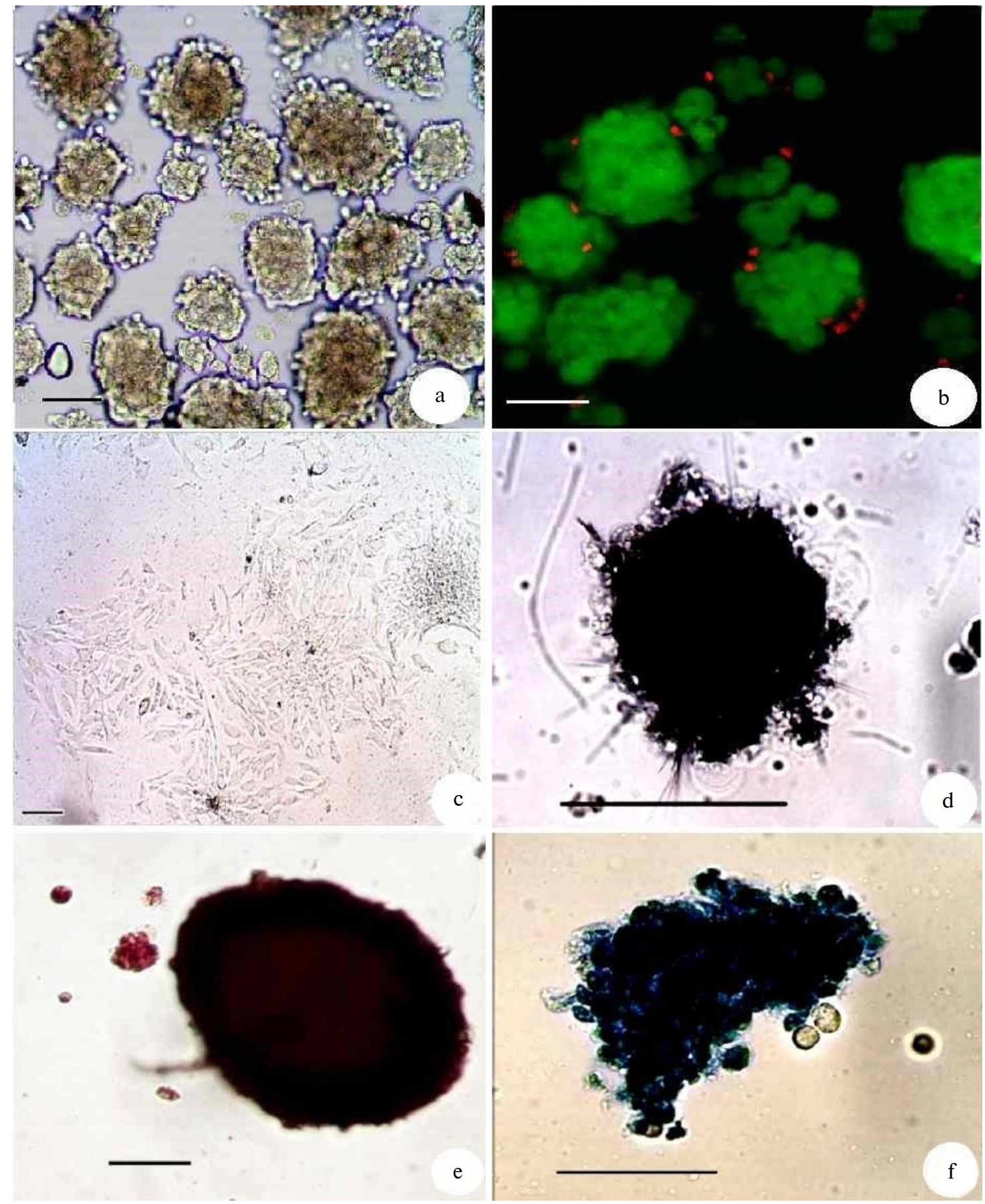

Figure 1: Placental MSCs spheroids: (a) phase contrast, (b) laser scanning confocal microscopy, FDA/PI staining, (c) cell monolayer, after spheroids adhesion to the plastic, (d) MTT staining, (e) neutral red staining, (f) trypan blue staining. Scale bar $100 \mu \mathrm{m}$

Table 1: Placental cells spheroids characterization after short-term storage under subonormothermic conditions $+20^{\circ} \mathrm{C}(M \pm m)$

\begin{tabular}{|c|c|c|c|}
\hline Storage time & Number of spheroids & $\begin{array}{c}\text { MTT test } \\
\text { (absorbance) }\end{array}$ & $\begin{array}{c}\text { Resazurin test } \\
\text { (\% of absorbance reduction) }\end{array}$ \\
\hline Control & $862.2 \pm 32.5$ & $2.0 \pm 0.05$ & $62.3 \pm 3.5$ \\
\hline $24 \mathrm{~h}$ & $725.8 \pm 28.3$ & $2.1 \pm 0.08$ & $57.8 \pm 4.3$ \\
\hline $48 \mathrm{~h}$ & $545.3 \pm 17.2^{*}$ & $1.8 \pm 0.03^{*}$ & $55.4 \pm 2.9^{*}$ \\
\hline $72 \mathrm{~h}$ & $458.6 \pm 20.9^{*}$ & $1.2 \pm 0.12^{*}$ & $39.5 \pm 3.8^{*}$ \\
\hline $96 \mathrm{~h}$ & $332.1 \pm 18.2^{*}$ & $1.0 \pm 0.07^{*}$ & $18.7 \pm 1.7^{*}$ \\
\hline
\end{tabular}

*Differences are significant with control $p<0.05$. 


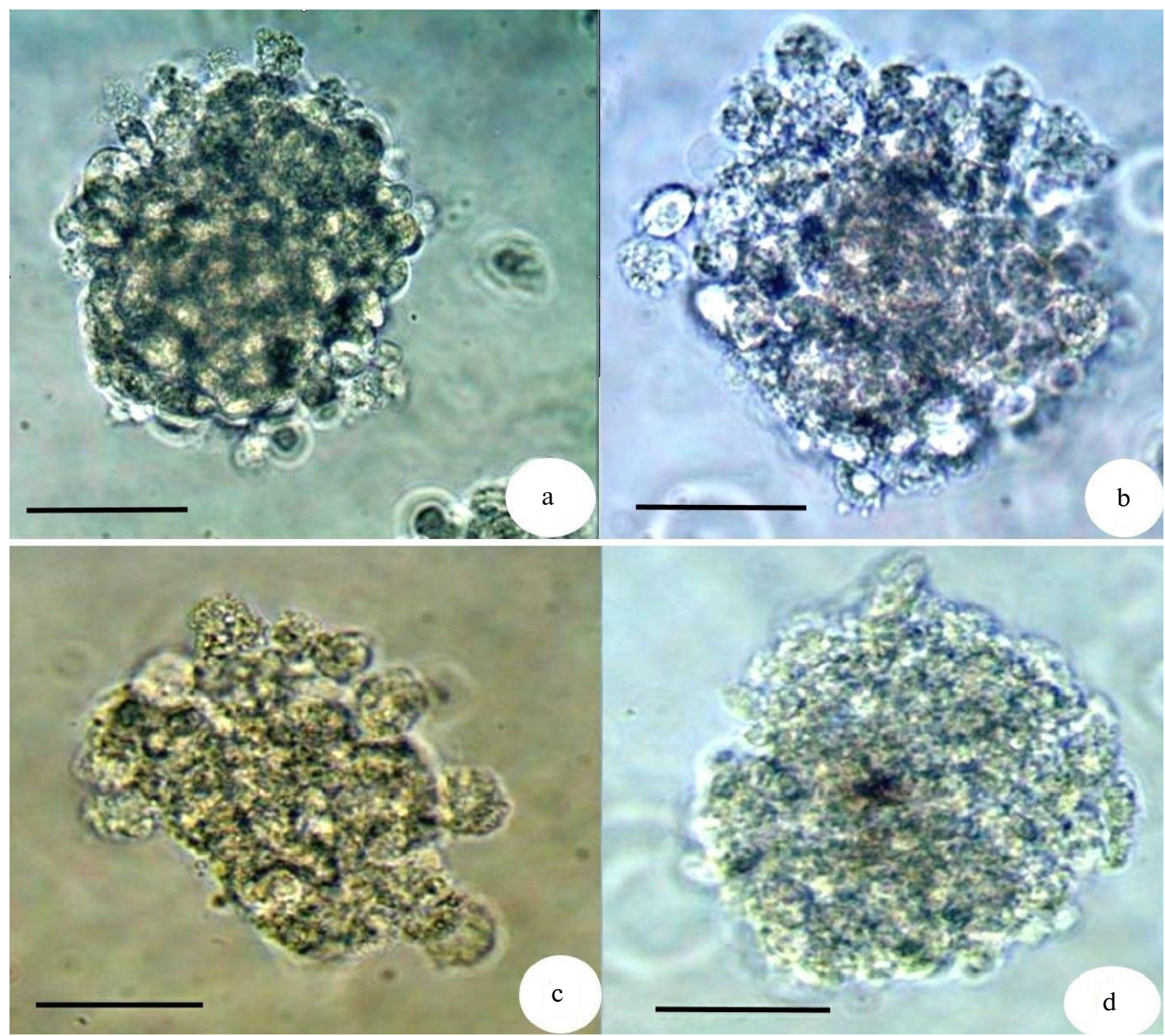

Figure 2: Placental MSCs spheroids: (a) $24 \mathrm{~h}$ of subnormothermic storage, (b) $48 \mathrm{~h}$ of subnormothermic storage, (c) $24 \mathrm{~h}$ of hypothermic storage, (d) $48 \mathrm{~h}$ of hypothermic storage. Scale bar $100 \mu \mathrm{m}$

Table 2: Placental cells spheroids characterization after short-term storage under hypothermic conditions $+20^{\circ} \mathrm{C}(M \pm m)$

\begin{tabular}{|c|c|c|c|}
\hline Storage time & Number of spheroids & $\begin{array}{c}\text { MTT test } \\
\text { (absorbance) }\end{array}$ & $\begin{array}{c}\text { Resazurin test } \\
\text { (\% of absorbance reduction) }\end{array}$ \\
\hline Control & $862.2 \pm 32.5$ & $2.0 \pm 0.05$ & $62.3 \pm 3.5$ \\
\hline $24 \mathrm{~h}$ & $550.9 \pm 26.7^{*}$ & $1.8 \pm 0.09^{*}$ & $52.1 \pm 4.1^{*}$ \\
\hline $48 \mathrm{~h}$ & $423.6 \pm 17.6^{*}$ & $1.3 \pm 0.07^{*}$ & $30.9 \pm 2.1^{*}$ \\
\hline $72 \mathrm{~h}$ & $259.8 \pm 10.2^{*}$ & $0.6 \pm 0.06^{*}$ & $24.6 \pm 1.9^{*}$ \\
\hline
\end{tabular}

*Differences are significant with control $p<0.05$.

\section{Discussion}

Thereby, it was shown, that the hanging drop method allows production of spheroids from placental MSCs. The cells connection in placental MSCs spheroids are not strong and they destroyed when washing, resuspensing or storage. So it is important to use non-adhesive plastics to preserve and transport placental MSCs spheroids to prevent adhesion.

For placental MSCs spheroids screening tests, it is advisable to apply a morphological study, try- pan blue staining and MTT test, to evaluate metabolic activity.

Placental MSCs spheroids storage is possible no more than one day at $20^{\circ} \mathrm{C}$. Storage at a longer time, or storage under hypothermic conditions, leads to spheroids disintegration. The ineffectiveness of spheroids long-term storage at low temperatures can be explained firstly by the fact that the enzyme systems of the homeothermic organism are not adapted to function under these conditions, and secondly by the phenomena of central ischemia. 
Placental MSCs spheroids instability in comparison with placental cells and explants, the impossibility of their cryopreservation limits spheroids application in clinical practice. Spheroids require careful handling and rapid delivery from the laboratory to the patient.

\section{Conclusions}

Hanging drop method allows to generate about 900 spheroids the size of $50-150$ microns from 1 million placental MSCs with preserved metabolic activity. For the medical application, it is advisable to use subonormothermic $\left(20^{\circ} \mathrm{C}\right)$ placental MSCs spheroids storage up to $24 \mathrm{~h}$, longer storage leads to a sharp metabolic activity decreasing and disintegration.

It is planned to study the effectiveness of placental MSCs spheroids application in experimental gynecological pathology.

\section{References}

[1] Silini AR, Cargnoni A, Magatti M, Pianta S, Parolini O. The long path of human placenta, and its derivatives, in regenerative medicine. Front Bioeng Biotechnol. 2015 Oct 19;3:162. DOI: 10.3389/fbioe.2015.00162

[2] Pogozhykh O, Prokopyuk V, Figueiredo C, Pogozhykh D. Placenta and placental derivatives in regenerative therapies: experimental studies, history, and prospects. Stem Cells Int. 2018;2018:14. DOI: 10.1155/2018/4837930

[3] Kim TH, Choi JH, Jun Y, Lim SM, Park S, Paek JY, et al. 3D-cultured human placenta-derived mesenchymal stem cell spheroids enhance ovary function by inducing folliculogenesis. Sci Rep. 2018 Oct 17;8(1):15313. DOI: 10.1038/s41598-018-33575-9

[4] Petrenko Y, Syková E, Kubinová Š. The therapeutic potential of three dimensional multipotent mesenchymal stromal cellspheroids. Stem Cell Res Ther. 2017;8(1):94. DOI: 10.1186/s13287-017-0558-6

[5] Giwa S, Lewis JK, Alvarez L, Langer R, Roth AE, Church GM, et al. The promise of organ and tissue preservation to transform medicine. Nat Biotechnol. 2017 Jun 7;35(6):530-42. DOI: 10.1038/nbt.3889

[6] Pogozhykh O, Prokopyuk V, Prokopyuk O, Kuleshova L, Goltsev A, Figueiredo C, et al. Towards biobanking technologies for natural and bioengineered multicellular placental constructs. Biomaterials. 2018;185:39-50. DOI: 10.1016/j.biomaterials.2018.08.060

[7] van de Kerkhove MP, Hoekstra R, van Nooijen FC, Spoelstra FO, Doorschodt BM, van Wijk AC, et al. Subnormothermic preservation maintains viability and function in a porcine hepatocyte culture model simulating bioreactor transport. Cell Transplant. 2006;15(2):161-8. DOI: 10.3727/000000006783982089

[8] Pogozhykh D, Prokopyuk V, Pogozhykh O, Mueller T, Prokopyuk O. Influence of factors of cryopreservation and hypothermic storage on survival and functional parameters of multipotent stromal cells of placental origin. PLoS One. 2015;10(10):e0139834. DOI: 10.1371/journal.pone.0139834

[9] Foty R. A simple hanging drop cell culture protocol for generation of 3D spheroids. J Vis Exp. 2011 May 6;51. DOI: $10.3791 / 2720$

[10] Pravdyuk AI, Petrenko YA, Fuller BJ, Petrenko AY. Cryopreservation of alginate encapsulated mesenchymal stromal cells. Cryobiology. 2013;66(3):215-22. DOI: 10.1016/j.cryobiol.2013.02.002

\section{ХАРАКТЕРИСТИКА СФЕРОЇДІВ ІЗ МЕЗЕНХІМАЛЬНИХ СТОВБУРОВИХ КЛІТИН ПЛАЦЕНТИ ПІСЛЯ ОТРИМАННЯ, ГІПОТЕРМІЧНОГО ТА СУБНОРМОТЕРМІЧНОГО ЗБЕРІГАННЯ}

Проблематика. Застосування мезенхімальних стовбурових клітини (МСК) плаценти є перспективним напрямом клітинної терапії низки захворювань. Їх застосування у формі сфероїдів зі збереженням міжклітинних контактів і паракринних взаємодій дає змогу підвищити активність клітин, подовжити час їх функціонування. Для ефективного медичного застосування необхідні характеристика властивостей і розробка можливості зберігання сфероїдів.

Мета роботи. Охарактеризувати сфероїди з МСК плаценти після отримання та низькотемпературного зберігання.

Матеріали і методи. Сфероїди отримували методом висячої краплі з мезенхімальних стовбурових клітин плаценти, характеризували після одержання та після субнормотермічного $\left(20^{\circ} \mathrm{C}\right)$ і гіпотермічного $\left(4^{\circ} \mathrm{C}\right)$ зберігання до 96 год. Досліджували структуру, метаболічну активність сфероїдів за даними МТТ-тесту і тесту відновлення резазурину.

Результати. Методом висячої краплі з $1 \times 10^{6}$ МСК плаценти клітин отримано близько 825,3 $\pm 56,2$ сфероїдів розміром 50150 мкм і 62,3 + 5,1 сфероїдів розміром 150-300 мкм, які мають сферичну форму, не забарвлюються трипановим синім, забарвлюються нейтральним червоним і флюоресцеїн діацетатом. Отримані сфероїди здатні до адгезії до пластику та руйнування при короткочасному центрифугуванні. При субнормотермічому зберіганні структурні характеристики та метаболічна активність сфероїдів вірогідно змінювалися після 48 год, при гіпотермічному - після 24 год зберігання.

Висновки. Методом висячої краплі можливе отримання близько 900 сфероїдів з 1 млн МСК плаценти зі збереженням метаболічної активності. Для потреб медицини оптимально застосовувати субнормотермічне $\left(20^{\circ} \mathrm{C}\right)$ зберігання сфероїдів МСК плаценти тривалістю до 24 год, подальше зберігання призводить до різкого зниження їх метаболічної активності та розпаду на окремі клітини.

Ключові слова: сфероїди; мезенхімальні стовбурові клітини; плацента; гіпотермія; субнормотермія. 
В.Ю. Прокопюк, Н.С. Глоба, О.С. Прокопюк, А.О. Щедров, И.Б. Мусатова

\section{ХАРАКТЕРИСТИКА СФЕРОИДОВ ИЗ МЕЗЕНХИМАЛЬНЫХ СТВОЛОВЫХ КЛЕТОК ПЛАЦЕНТЫ ПОСЛЕ ПОЛУЧЕНИЯ, ГИПОТЕРМИЧЕСКОГО И СУБНОРМОТЕРМИЧЕСКОГО ХРАНЕНИЯ}

Проблематика. Использование мезенхимальных стволовых клеток (МСК) плаценты является перспективным направлением клеточной терапии ряда заболеваний. Их применение в форме сфероидов с сохранением межклеточных контактов и паракринных взаимодействий позволяет повысить активность клеток, продлить время их функционирования. Для эффективного медицинского применения необходимы характеристика свойств и разработка возможности хранения сфероидов.

Цель работы. Охарактеризовать сфероиды из МСК плаценты после получения и низкотемпературного хранения.

Материалы и методы. Сфероиды получали методом висячей капли из МСК плаценты, характеризовали после получения и субнормотермического $\left(20^{\circ} \mathrm{C}\right)$ и гипотермического $\left(4^{\circ} \mathrm{C}\right)$ хранения до 96 ч. Исследовали структуру, метаболическую активность сфероидов по данным МТТ-теста и теста восстановления резазурина.

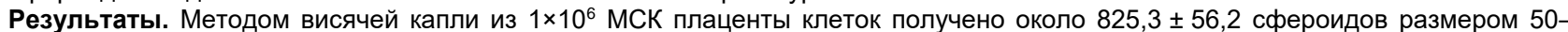
150 мкм и 62,3 × 5,1 сфрероидов размером 150-300 мкм, которые имеют сферическую фрорму, не окрашиваются трипановым синим, окрашиваются нейтральным красным и флюоресцеин диацетатом. Полученные сфероиды способны к адгезии к пластику и разрушению при кратковременном центрифугировании. При субнормотермическом хранении структурные характеристики и метаболическая активность сфероидов достоверно изменялись после 48 ч, при гипотермическом - после 24 ч хранения.

Выводы. Методом висячей капли возможно получение около 900 сорероидов из 1 млн МСК плаценты с сохранением метаболической активности. Для нужд медицины целесообразно применять субнормотермическое (20 $\left.{ }^{\circ} \mathrm{C}\right)$ хранение сфероидов МСК плаценты до 24 ч, дальнейшее хранение приводит к резкому снижению их метаболической активности и распаду на отдельные клетки.

Ключевые слова: сфероиды; мезенхимальные стволовые клетки; плацента; гипотермия; субнормотермия. 